Treatment may reduce the growth rate of tumor cells without eliminating them. Microscopic metastases may be eliminated as well."

Cellcor's commercial patients haven't fared as well as its clinical trial patients. Preliminary data show that the 450 patients treated commercially have survived an average of just 10 months. "The commerical patients with more severe cancer than the clinical trial patients haven't survived as long. But commerical patients with cancer severity similiar to the clinical trial patients have similiar survival rates," says Richard D'Antoni, Cellcor's chief executive officer.

\section{Pivotal trial}

An upcoming clinical trial may determine whether or not Cellcor's therapy really works. The Eastern Cooperative Oncology Group-a large network of academic oncologists-will conduct a phase III trial of 200 metastatic RCC patients that compares Cellcor's therapy to low doses of alpha interferon and interleukin-2, a treatment currently considered the best available therapy for metastatic RCC. "Cellcor will rise or fall with the trial's results,"says UCLA's Figlin, the principal investigator of the trial, which may begin later this year.

At least one Wall Street analyst still believes in Cellcor. Steve Buell of Furman Selz (New York) - the lead underwriter for Cellcor's IPO - sees the company's revenues reaching $\$ 5$ million this year, up from $\$ 1.5$ million last year. He expects Cellcor-a loser of $\$ 9.8$ million in 1991 - to break even in early 1994, with earnings reaching $\$ 1$ a share in early 1995.

Several third-party payers also believe in Cellcor. The third-party reimbursement rate for Cellcor's therapy reached 57 percent in this year's first quarter, a high rate for an expensive treatment without marketing approval from the Food and Drug Administration (FDA, Bethesda, MD). Overall, 70 insurance companies, 10 health maintenance organizations, and several state Medicare agencies have reimbursed the therapy.

But a potential partner recently lost faith in Cellcor. Cellcor and Critical Care America (CCA, Nashua, NH), a provider of out-patient care, had planned tojointly market Cellcor's therapy for metastatic RCC and, potentially, for HIV infection. CCA backed out of the deal because it was "more interested in AIDS treatment than cancer therapy," says Furman Selz's Buell. He adds, "Clearly, the loss of CCA as a partner for Cellcor is negative from the perspective of external validation by a large, experienced, and respected health-care provider."

-B.J. Spalding
WEAK THIRD QUARTER

\section{WINDOW STILL CLOSING}

NEWYORK-As thisyear's third quarter ended, the record-shattering 1991/1992 public-financing window for U.S. biotechnology companies continued to close. The quarter saw just eight companies raise $\$ 156.4$ million, a performance similar to this year's second quarter, in which 10 companies raised $\$ 161.1 \mathrm{mil}$ lion (Table 1). In comparison, 1991 and the first quarter of 1992 saw 132 companies raise $\$ 5$ billion.

The public-financing window is closing because biotech stock prices have dropped an average of 50 percent, after reaching all-time highs in January. With so many companies trading at substantial discounts to their recent highs, investors are more likely to invest in existing companies than in initial public offerings (IPOs) or even secondary offerings.

Biotech stocks
The quarter saw just eight companies raise $\$ 156.4$ million, $a$ performance similar to this year's second quarter.
This followed the Food and Drug Administration's (FDA, Bethesda, MD) refusal to approve the high-profile sepsis products of Centocor (Malvern, PA) and Xoma (Berkeley, CA), an FDA advisory committee's nixing of U.S. Bioscience's (W. Conshohocken, PA) chemoprotectant, and MGI Pharma's (Minneapolis, MN) halting of phase III trials of its chemoprotectant.

This year's third-quarter offerings, for their part, included five IPOs that brought in $\$ 93.3$ million and three secondary offerings that captured $\$ 63.1$ million. At the quarter's start, by comparison, 29 IPOs and six secondary offerings were in process. The quarter opened relatively quickly, before financing ground to a halt. In July, six companies raised $\$ 108.9$ million, while August saw two companies bring in $\$ 47.5$ million and September saw no money raised.

Indeed, several have plunged because of this year's series of setbacks. (San Diego, CA) share price plummeted 38 percent, from $\$ 35.6$ to $\$ 22$, after it disclosed disappointing clinical results for its lead product, a heart-surgerydrug. Most recently, Gensia Pharmaceuticals's firms turned to private investors during the quarter. Cephalon (W. Chester, PA) raised $\$ 45$ million privately, while Arris Pharmaceutical (S. San Francisco, CA) completed a $\$ 15.5$ million private placement. -B.J. Spalding
TABLE 1. BIOTECH'S 1992 THIRD-QUARTER OFFERINGS

\begin{tabular}{|c|c|c|c|c|}
\hline Company & Target & Date & $\begin{array}{l}\text { Money } \\
\text { Raised } \\
\text { (\$ Millions) }\end{array}$ & $\begin{array}{l}\text { Post-Money } \\
\text { Valuation } \\
\text { (\$ Millions) }\end{array}$ \\
\hline
\end{tabular}

\begin{tabular}{|lllll}
\hline Initial Public Offerings & & & & \\
British Bio-technology & Vaccines & $7 / 92$ & $\$ 57.0$ & $\$ 290.9$ \\
Argus Pharmaceuticals & Cancer Therapeutics & $7 / 92$ & 11.9 & 46.2 \\
Cantab Pharmaceuticals & Autoimmune Diseases & $7 / 92$ & 10.0 & 60.0 \\
Envirogen & Waste Management & $8 / 92$ & 8.6 & 41.1 \\
Matritech & Cancer Diagnostics & $7 / 92$ & 5.8 & 21.3 \\
Subtotals & & & $\mathbf{9 3 . 3}$ & $\mathbf{4 5 9 . 5}$ \\
\hline
\end{tabular}

Secondary Public Offerings

Somatogen

Quadra Logic Technologies

Blood Substitute $\quad 8 / 92$

38.9

180.5

Crop Genetics International

Cancer Therapeutics

$7 / 92$

14.2

84.6

Subtotals

Engineered Plants

$7 / 92$

10.0

42.8

Combined Totals

63.1

307.9

156.4

767.4 